\title{
Study of risk factors for preterm deliveries in a tertiary hospital
}

\author{
Sapna D. Berry ${ }^{1 *}$, Rajeev Sood ${ }^{1}$, Kalpna Negi ${ }^{1}$, Naveen Kumar ${ }^{2}$
}

\begin{abstract}
${ }^{1}$ Department of Obstetrics and Gynecology, IGMC Shimla, Himachal Pradesh, India
\end{abstract}
${ }^{2}$ Department of Pediatrics, IGMC Shimla, Himachal Pradesh, India

Received: 15 May 2020

Accepted: 05 June 2020

*Correspondence:

Dr. Sapna D. Berry,

E-mail: sapnab4@gmail.com

Copyright: (c) the author(s), publisher and licensee Medip Academy. This is an open-access article distributed under the terms of the Creative Commons Attribution Non-Commercial License, which permits unrestricted non-commercial use, distribution, and reproduction in any medium, provided the original work is properly cited.

\begin{abstract}
Background: Preterm labour and preterm deliveries are very challenging obstetric complications. Early identification of risk factors may help identify women at risk for preterm deliveries.

Methods: A one-year observational study was conducted in the department of obstetrics and gynecology, IGMC Shimla, Himachal Pradesh from $1^{\text {st }}$ August 2017 to $31^{\text {st }}$ July 2018. All mothers who delivered between 24 to 37 weeks were subjected to a detailed history with respect to age, parity, previous pregnancy outcomes and to identify the presence of any risk factors. A thorough obstetric and systemic examination was done. Parametric and non-parametric test of significance were used to find the association between different quantitative and qualitative variable.

Results: Incidence of preterm deliveries was 11.4\%. Maximum cases were of age group 25-30 years. $71.7 \%$ belonged to lower socio-economic status. $54 \%$ cases were seen in multigravida. History of previous abortion was seen in $18.4 \%$ and $9.7 \%$ had history of preterm deliveries. $12 \%$ cases had history of $1^{\text {st }}$ trimester bleeding. Spontaneous onset of preterm labour was seen in $55.1 \%$. The significant risk factors associated were PIH and genitourinary infections.

Conclusions: The risk factors of preterm birth to a large extent can be identified in antenatal period. Adolescent health education including good nutrition, good hygiene, counselling for contraception to reduce unintended pregnancies and birth spacing can lower the preterm birth rate. Better prenatal care, early identification of risk factors and complicated cases, regular follow up and proper management can help us in reducing preterm births.
\end{abstract}

Keywords: Etiology, Preterm labour, Risk factors

\section{INTRODUCTION}

The World Health Organization defines preterm birth as any birth before 37 completed weeks of gestation or fewer than 259 days since the first day of woman's last menstrual period. ${ }^{1}$

Incidence of preterm delivery is 1 in 10 births (11\%) in USA and even greater births in developing countries. Around $40-75 \%$ neonatal deaths are attributable to preterm deliveries. Estimates of preterm birth rates range from $5-10 \%$ in developed countries to $25 \%$ in developing countries. In India, incidence of preterm labour is $23.3 \%$ and of preterm delivery is $10-69 \% .^{2}$ Preterm birth is a worldwide problem and to draw attention to it, since
2011, November 17 is celebrated as World's prematurity day. ${ }^{3}$

Preterm births can be divided on the basis of gestational age into:

- Late preterm births: between 34-36 weeks

- Early preterm birth: between 32-34 weeks

- Very preterm birth: between 28-32 weeks

- Extreme preterm birth: before 28 weeks. ${ }^{4}$

\section{The preludes leading to preterm birth include}

- Spontaneous labour with intact membranes (40-55\%)

- $\quad$ Preterm rupture of membranes (30\%) 
- Medically indicated or elective preterm birth (15$20 \%)^{5}$

American college of obstetrics and gynecology proposed the following criteria to diagnose preterm labour:

- Contraction of 4 in 20 minutes or 8 in 60 minutes plus progressive cervical change

- Cervical dilatation greater than $1 \mathrm{~cm}$

- Cervical effacement of $80 \%$ or $^{-}$greater. $^{2}$

Prelabour rupture of membranes (PROM) is defined as the spontaneous rupture of amniotic membrane with a release of amniotic fluid at least one hour before the onset of labour. If the membranes before 37 weeks of gestation, it is termed as the preterm prelabour rupture of membrane (PPROM). Latent period is the time interval between the rupture of membranes and the onset of uterine contractions. Prolonged PROM is the term used when more than 24 hours have elapsed before the labour ensues. ${ }^{6}$ Incidence of PPROM ranges from 3\%-10\% of all the deliveries. It leads to one third of preterm births. ${ }^{7}$

\section{METHODS}

This was a one-year observational study, conducted in the Department of obstetrics and gynecology IGMC Shimla Himachal Pradesh from $1^{\text {st }}$ August 2017 to $31^{\text {st }}$ July 2018.

\section{Inclusion criteria}

- Women with gestation age >24 weeks to <37 weeks who had spontaneous onset preterm labour and preterm premature rupture of membranes were included in the study. Medically indicated or elective preterm deliveries were also included in the study.

\section{Exclusion criteria}

- $\quad$ Pregnancy beyond 37 weeks

- Any congenital malformations such as anencephaly, hydrocephalus or multiple congenital anomalies

- Multiple pregnancies.

The data was collected from mother case sheet and included age, parity, booking status, socio-economic status, gestation age, previous obstetric history, medical/obstetric complications in present pregnancy, cause of preterm delivery, if any, treatment profile.

Those subjects where induction of labour was done due to any medical or obstetrical indication, indication for induction and mode of delivery was recorded.

\section{RESULTS}

There were 6533 deliveries in the hospital during study period of which 720 were preterm deliveries, giving incidence of $11.4 \%$. Out of 720 preterm deliveries 630 subjects fulfilled the inclusion criteria and were included in the study.

Maximum numbers of the subjects accounting for $45.1 \%$ were in age group of 25-30 years followed by $30.1 \%$ of age group 21-24 years, $16.2 \%$ of age group $>30$ years and $8.6 \%$ of age group $<20$ years (Table 1 ).

Table 1: Distribution of cases according to age.

\begin{tabular}{|lll|}
\hline Age group & No. of cases & Percentage $(\mathbf{n = 6 3 0})$ \\
\hline$<20$ years & 54 & $8.6 \%$ \\
\hline 21-24 years & 190 & $30.1 \%$ \\
\hline 25-30 years & 284 & $45.1 \%$ \\
\hline$>30$ years & 102 & $16.2 \%$ \\
\hline
\end{tabular}

A total $71.7 \%$ cases belonged to lower socio-economic status and middle socio-economic status group had $26.3 \%$ cases while upper socio-economic status group constituted only $2 \%$ of the cases (Table 2).

Table 2: Distribution of cases according to socioeconomic status.

\begin{tabular}{|lll|}
\hline $\begin{array}{l}\text { Socio-economic } \\
\text { status }\end{array}$ & No. of cases & $\begin{array}{l}\text { Percentage } \\
(\mathbf{n}=\mathbf{6 3 0})\end{array}$ \\
\hline Lower class & 452 & $71.7 \%$ \\
\hline Middle class & 166 & $26.3 \%$ \\
\hline Upper class & 12 & $2 \%$ \\
\hline
\end{tabular}

Table 3: Distribution according to obstetrics score.

\begin{tabular}{|lll|}
\hline Gravidity & No. of cases & Percentage $(\mathbf{n}=\mathbf{6 3 0})$ \\
\hline Primigravida & 290 & $46 \%$ \\
\hline Multigravida & 340 & $54 \%$ \\
\hline
\end{tabular}

A total $54 \%$ cases were seen in multigravida and $46 \%$ were seen in primigravida (Table 3 ).

Table 4: Distribution according to previous obstetrics outcomes.

\begin{tabular}{|lll|}
\hline Previous history & No. of cases & $\begin{array}{l}\text { Percentage } \\
(\mathbf{n = 6 3 0})\end{array}$ \\
\hline Abortion & 116 & $18.4 \%$ \\
\hline Preterm delivery & 61 & $9.7 \%$ \\
\hline
\end{tabular}

In $18.4 \%$ cases there was history of previous abortion while $9.7 \%$ cases had previous history of preterm delivery (Table 4).

A total $12 \%$ cases that had preterm deliveries were also having history of bleeding in $1^{\text {st }}$ trimester (Table 5).

Among the various medical complications $20.3 \%$ cases were having hypertension, $18.7 \%$ had genitourinary infections, $7.6 \%$ cases had subclinical hypothyroidism $5.1 \%$ had severe anaemia, $2.8 \%$ cases were having GDM, $2.2 \%$ cases had ICP and $0.8 \%$ cases were having heart 
disease. Most common complication was hypertension (Table 6).

Table 5: Distribution according to history of $1^{\text {st }}$ trimester bleeding.

\begin{tabular}{|lll|}
\hline $\begin{array}{l}\text { H/o } 1^{\text {st }} \text { trimester } \\
\text { bleeding }\end{array}$ & No. of cases & $\begin{array}{l}\text { Percentage } \\
(\mathbf{n = 6 3 0})\end{array}$ \\
\hline Present & 75 & $12 \%$ \\
\hline Absent & 555 & $88 \%$ \\
\hline
\end{tabular}

Table 6: Associated medical complications in pregnancy.

\begin{tabular}{|lll|}
\hline Complications & $\begin{array}{l}\text { No. of } \\
\text { cases }\end{array}$ & $\begin{array}{l}\text { Percentage } \\
(\mathbf{n = 6 3 0})\end{array}$ \\
\hline Hypertension & 128 & $20.3 \%$ \\
\hline Genitourinary infections & 118 & $18.7 \%$ \\
\hline S/C hypothyroidism & 48 & $7.6 \%$ \\
\hline Severe anaemia & 32 & $5.1 \%$ \\
\hline GDM & 18 & $2.8 \%$ \\
\hline ICP & 14 & $2.2 \%$ \\
\hline Heart disease & 5 & $0.8 \%$ \\
\hline
\end{tabular}

Among the various obstetrics complications $5.1 \%$ cases were having IUGR, $4.8 \%$ cases were of malpresentation, $4 \%$ were having previous LSCS, $3.8 \%$ cases had abruptio placenta and $2.5 \%$ were of placenta praevia. Most common obstetric complication associated with preterm deliveries was IUGR (Table 7).

Table 7: Associated obstetrics complications in pregnancy.

\begin{tabular}{|lll|}
\hline Complications & $\begin{array}{l}\text { No. of } \\
\text { cases }\end{array}$ & Percentage $(\mathbf{n = 6 3 0})$ \\
\hline IUGR & 32 & $5.1 \%$ \\
\hline Malpresentation & 30 & $4.8 \%$ \\
\hline Previous LSCS & 25 & $4 \%$ \\
\hline Abruptio placenta & 24 & $3.8 \%$ \\
\hline Placenta previa & 16 & $2.5 \%$ \\
\hline
\end{tabular}

Table 8: Distribution according to cause of preterm.

\begin{tabular}{|lll|}
\hline Type & No. of cases & Percentage $(\mathbf{n = 6 3 0})$ \\
\hline Spontaneous & 347 & $55.1 \%$ \\
\hline PPROM & 217 & $34.4 \%$ \\
\hline Iatrogenic & 66 & $10.5 \%$ \\
\hline
\end{tabular}

In this study $55.1 \%$ cases had preterm delivery due to spontaneous onset of preterm labour, $34.4 \%$ were due to PPROM and $10.5 \%$ cases had iatrogenic preterm deliveries for some maternal and fetal indications (Table 8).

In iatrogenic preterm deliveries most, common indication was PIH (37.9\%) followed by APH $(30.3 \%)$, severe IUGR (28.8\%) and (3.0\%).

\section{DISCUSSION}

Preterm labour is an obstetrics emergency and a threat to population health. $75 \%$ of the infant mortality is related to preterm birth. The vast majority $(85 \%)$ of global preterm births occur in Asian and African continents, where health systems are weak and inadequate as per the standards of developed nations. ${ }^{8}$

Incidence of preterm birth in this study was $11.02 \%$. This was in accordance with the study by Das A et al, and Prakash SA et al in which the incidence of preterm birth was $10.2 \%$ and $6.7 \%$ respectively. ${ }^{2,5}$ It was $27.9 \%$ in study of Gupta $\mathrm{N}$ et al. ${ }^{9}$

\section{Age incidence}

Most cases accounting for $45.1 \%$ in this study were in the age group of 25-30 years. In the studies by Radhanpuri $\mathrm{F}$ et al, Fernandes SF et al and Shetty MB et al, $42.6 \%$ $35.7 \%$ and $44 \%$ of cases were of age group 25-30 years respectively. ${ }^{10-12}$ This age group being the most common period for marriage and childbearing accounted for higher incidence of preterm birth in this age.

\section{Socio-economic incidence}

In this study maximum numbers of cases belonged to low socio-economic status which accounted for $71.7 \%$ in comparison to other studies conducted by Radhanpuri $\mathrm{F}$ et al, Mahajan A et al and Gupta $\mathrm{N}$ et al where 51\%, 58\% and $56.3 \%$ were from low socio-economics status respectively, which shows that preterm births are more common in low socio-economic status..$^{9,10,13}$

\section{Gravidity incidence}

A total $54 \%$ cases of preterm deliveries in this study were seen in multigravida. This was similar to studies by Singh $\mathrm{U}$ et al, Fernandes SF et al, and Shetty MB et al in which it was $53 \%, 54.4 \%$ and $57.4 \%$ respectively. ${ }^{11,12,14}$

\section{Previous obstetrics outcomes}

Present study showed that previous history of abortion was present in $18.4 \%$ cases and history of previous preterm delivery was present in $9.7 \%$. This is similar to study by Gupta $\mathrm{N}$ et al where these histories were present in $18.8 \%$ and $11.6 \%$ of the cases respectively. ${ }^{9}$ In a study by Singh U et al similar histories were present in $14.4 \%$ of cases. ${ }^{14}$ Similar observations were even seen in a study by Mahajan A et al, where $25 \%$ cases had previous $\mathrm{H} / \mathrm{O}$ abortion and $26 \%$ had previous $\mathrm{H} / \mathrm{O}$ preterm delivery. ${ }^{15}$

Association with abortion could be attributed to cervical trauma from mechanical dilatation and suction and evacuation, which do increase the risk of cervical incompetence and facilitates upper genital tract infection also. 


\section{$1^{\text {st }}$ trimester bleeding}

In this study $\mathrm{H} / \mathrm{O} 1 \mathrm{st}$ trimester bleeding was present in $12 \%$ of the cases which was similar to study by Rao CR et al, in which it was present in $9.1 \%$ of the cases. ${ }^{1}$

\section{Associated risk factors}

- Hypertension was present in $20.3 \%$ of the cases in this study which was in accordance to the studies by Fernandes SF et al, Prakash SA et al, and Mahajan A et al, in which it was present in $21.07 \%, 12.5 \%$ and $20 \%$ of the cases respectively. ${ }^{2,11,13}$ Hypertension causes vasospasm and leads to IUGR. It also causes increased incidence of abruption leading to preterm deliveries, either spontaneous or iatrogenic.

- Genitourinary infections were present in $18.7 \%$ of the cases in this study which were correlating with the studies by Fernandes SF et al in which these were present in $13.6 \%$ and Prakash SA et al in which these were seen in $10.4 \%$ cases respectively. ${ }^{2,11}$

- A total $5.1 \%$ cases were of anaemia in present study and it was seen in $2.7 \%$ in study by Fernandes SF et al, $2.08 \%$ in Prakash SA et al. ${ }^{2,11} 2.9 \%$ in Shetty MB et al and $7 \%$ in study by Mahajan A et al. ${ }^{12,13}$

- Hypothyroidism was seen in $7.6 \%$ of the cases in this study which was similar to the study by Shetty MB et al, in which it was seen in $9.9 \%$ of the cases. ${ }^{12}$ It was $0.5 \%$ and $1.04 \%$ in the studies of Fernandes SF et al, and Prakash SA et al. ${ }^{2,11}$ Incidence of hypothyroidism was more in this study because study is conducted in sub Himalayan region of country in which iodine deficiency is common.

- Association with the GDM was seen in $2.8 \%$ of the cases which was similar to the studies of Fernandes SF et al, Prakash SA et al, Shetty MB et al, and Mahajan A et al in which it was present in $3.4 \%$, $4.1 \%, 3.8 \%$ and $2 \%$ respectively. ${ }^{2,11,12,13}$

- Heart disease was seen in $0.8 \%$ of the cases in this study. It was similar to the study by Fernandes SF et al and Shetty MB et al in which it was seen in $0.5 \%$ and $0.9 \%$ respectively. ${ }^{11,12}$

- Association with IUGR was $5.1 \%$ in this study and $2.08 \%$ in study by Prakash SA et al. ${ }^{2}$ High incidence of IUGR in present study is due to a greater number of cases belonging to high altitude areas where incidence of IUGR is higher and also a greater number of cases from low socio-economic status in this study.

- APH was seen in $6.3 \%$ of the cases in present study which was in accordance with studies of Fernandes SF et al and Prakash SA et al where it was seen in $11 \%$ and $9.4 \%$ respectively. ${ }^{2,11}$ In $\mathrm{APH}$, the rate of iatrogenic preterm deliveries increases in view of maternal and fetal well-being.

- Association with malpresentation was seen in $4.7 \%$ of the cases in this study which is correlating with the study by Prakash MB et al and Shetty MB et al, in which it was present in $5.2 \%$ and $8.2 \%$ of the cases respectively. ${ }^{2,12}$ Malpresentation at preterm gestation is a known association in comparison to term gestation.

\section{Cause of preterm deliveries}

Maximum preterm deliveries in this study were due spontaneous onset of labour which constituted $55.1 \%$ of the total preterm deliveries. Similarly, in other studies also, spontaneous onset of preterm labour was the most common cause of preterm. It was $45 \%$ in study by McIntire DD et al, $31.7 \%$ in Henderson $\mathrm{JJ}$ et al and $56.05 \%$ in study by Das A et al. ${ }^{5,15,16}$

The second most common cause of preterm deliveries was PPROM which was seen in $34.4 \%$ of the cases. It was consistent with the other studies as $35 \%$ in study by McIntire DD et al, $27.4 \%$ by Henderson JJ et al and $21.8 \%$ by Das A et al. ${ }^{4,15,19}$

Iatrogenic preterm deliveries accounted for $10.5 \%$ of the cases in this study while it was seen in $20 \%$ of the cases in study by McIntire DD et al and $22.1 \%$ in studies by Henderson JJ et al and Das A et al. ${ }^{5,15,16}$

\section{ACKNOWLEDGMENTS}

Authors express their heartfelt gratitude to their colleagues of obstetrics and gynecology department for collecting data and undoubtedly to the antenatal patients without whom this work could not have been possible.

\section{Funding: No funding sources \\ Conflict of interest: None declared \\ Ethical approval: Not required}

\section{REFERENCES}

1. Rao CR, de Ruiter LE, Bhat P, Kamath V, Kamath A, Bhat V. A case-control study on risk factors for preterm deliveries in a secondary care hospital, southern India. Obstet Gynecol. 2014;2014:935982.

2. Prakash SA, Rasquinha S, Rajaratnam A, Lavanya S. Analysis of risk factors and outcome of preterm labor. Int J of Eng Sci. 2016;6(8):2602-4.

3. Platt MJ. Outcomes in preterm infants. Public Health. 2014;128(5):399-403.

4. Naik S, Singh A. Preterm birth: its causes and perinatal outcome. Int J Sci Res. 2018;6(5):501-3.

5. Das A, Panda S, Ahanthem SS, Sourabh GD, Bhanu Partap SG. Preterm birth: analysis of risk factors and neonatal outcomes. Gynecol Obstet Case Rep. 2015;1:1-5.

6. Mohokar SA, Bava AK, Nandanwar YS. Analysis of maternal and perinatal outcome in cases of preterm premature rupture of membranes. Bombay Hospital. 2015;57(3):285-96.

7. Dars S, Malik S, Samreen I, Kazi RA. Maternal morbidity and perinatal outcome in preterm 
premature rupture of membranes before 37 weeks gestation. Pak J Med Sci. 2014;30(3):626-9.

8. Shah R, Mullany LC, Darmstadt GL, Mannan I, Rahman SM, Talukder RR, et al. Incidence and risk factors of preterm birth in a rural Bangladeshi cohort. BMC Pediatr. 2014;14:112-22.

9. Gupta N, Divedi P, Dwivedi D. Preterm labour and its effect on perinatal morbidity and mortality. Int $\mathrm{J}$ Reprod, Contracept Obstet Gynecol. 2018;7(5):19936.

10. Radhanpuri F, Desai DA, Sharma J, Kaur P. Preterm birth and its outcome. Int J Reprod Contracept Obstet Gynecol. 2014;3(1):153-7.

11. Fernandes SF, Chandra S. A study of risk factors for preterm labour. Int $\mathrm{J}$ Reprod Contracept Obstet Gynecol. 2015;4(5):1306-12.

12. Shetty MB, Krupa BM, Malyala M, Swarup A, Pathadan DS, Pocha S. Preterm birth: associated risk factors and outcome in tertiary care center. Int $\mathbf{J}$ Reprod Contracept Obstet Gynecol. 2017;6(8):32714.

13. Mahajan A, Magon S. Study of risk factors for preterm births in a teaching hospital: a prospective study. Int J Med and Dent Sci. 2017;6(1):1407-12.
14. Singh U, Singh N, Seth S. A prospective analysis of etiology and outcome of preterm labor. J Obstet Gynecol India. 2007;57(1):48-52.

15. McIntire DD, Leveno KJ. Neonatal mortality and morbidity rates in late preterm births compared with births at term. Obstet Gynecol. 2008;111(1):35-41.

16. Henderson JJ, McWilliam OA, Newnham JP, Pennell CE. Preterm birth etiology 2004-2008. Maternal factors associated with three phenotypes: spontaneous preterm labour, preterm pre-labour, rupture of membranes and medically indicated preterm birth. J Matern Fetal Neonatal Med. 2012;25(6):642-7.

Cite this article as: Berry SD, Sood R, Negi K, Kumar N. Study of risk factors for preterm deliveries in a tertiary hospital. Int J Reprod Contracept Obstet Gynecol 2020;9:3032-6. 